\title{
Optimal capacity in the Banking Sector and Economic Growth*
}

\author{
Bruno AMABLE ${ }^{\dagger} \quad$ Jean-Bernard CHATELAIN ${ }^{\ddagger}$ \\ Olivier DE BANDT ${ }^{\S}$ \\ PostPrint, published in: \\ Journal of Banking and Finance, 2002, 26, pp.491-517.
}

\begin{abstract}
The paper investigates, from the welfare and growth point of view, the determination of the optimal capacity of the banking system. For that purpose, we consider an overlapping generation model with endogenous growth. There is horizontal differentiation and imperfect competition in the banking sector. Macroeconomic shocks affect the return on capital and, together with the expectations of depositors, condition the stability of the banking sector. We specify to what extent deposit insurance may reduce instability and increase the number of deposits, welfare and growth. We also characterize the conditions under which excess banking capacities may appear and how their reduction may improve welfare.
\end{abstract}

JEL classification numbers : 016 G21

Keywords: Deposit Insurance, Imperfect Competition, Growth, Banking.

\footnotetext{
Opinions expressed here are those of the authors and do not necessarily reflect the views of the institutions to which they belong. They acknowledge helpful comments from participants in ESEM and EEA meetings and in the Federal Reserve Bank of Chicago symposium: "Risk management in the Global Economy: Measurement, Management and Macroeconomic Implications", in particular Stephen Smith and David Marshall. Forthcoming, Journal of Banking and Finance.

University of Paris X and CEPREMAP, 48 Boulevard Jourdan, 75014, Paris, France. Email: bruno.amable@cepremap.ens.fr

Corresponding author: Banque de France, 41-1391 Centre de Recherche, F-75049 Paris, cedex 01, France. Fax : 33.1.42.92.27.66. Tel : 33.1.42.92.49.58. E-mail address: jeanbernard.chatelain@banque-france.fr

Banque de France, 41-1376 SEMEP, F-75049 Paris cedex 01, France. E-mail address: olivier.debandt@banque-france.fr
} 


\section{Résumé}

Cet article étudie la détermination des capacités optimales du secteur bancaire du point de vue de la croissance et du bien-être. Nous considérons un modèle à générations imbriquées avec croissance endogène. Le secteur bancaire est caractérisé par une différentiation horizontale et de la concurrence imparfaite. Des chocs macroéconomiques altèrent le rendement du capital et peuvent porter atteinte à la stabilité du secteur bancaire, de même que les anticipations des déposants. Nous spécifions comment l'assurance sur les dépôts peut réduire l'instabilité et augmenter le nombre de déposants, le bien-être et la croissance. Nous précisons aussi les conditions sous lesquelles des capacités bancaires excédentaires peuvent apparaître et comment leur réduction peut accroître le bien-être économique.

\section{Classification JEL : 016 G21}

Mots-Clés: Assurance sur les dépôts, concurrence imparfaite, Croissance, Banques. 


\section{Introduction}

Over the last 15 years, in a context of increasingly global and deregulated markets, banking sectors in a number of countries around the world have experienced a significant increase in the number of branches. In many cases, this movement has led to the emergence of excess capacity (See Frydl,1993, for the US and Davis and Salo,1998, for the European Union). Although the concept of banking capacity is difficult to define, one of its most worrisome consequences is the growing instability of the banking sector. Excess capacity is usually associated with low profitability and therefore increasing risk of failures. It is clear, in particular, that many of the recent banking crises, like the US Savings and Loans debacle, the Scandinavian banking crisis in the early 1990s and in the Japanese banking system have been associated with some sort of excess capacity (see also Allen and Gale, 1999). In that case, the end of the crisis often required some restructuring of the banking sector through the closure of unprofitable and risky institutions. Such a "boom-bust cycle" has direct consequences for the growth of the economy.

There are two ways to circumvent the problem of instability. First, a safety net, in the form of deposit insurance, may be introduced in order to reduce the risk of failures. However the potentially huge cost of deposit insurance in the face of systemic risk can exceed its benefit. Public expenditure to meet deposit insurance claims and recapitalize banks have been sizeable, amounting to nearly 3\% of annual GDP in the US and Norway, 5 to $7 \%$ Sweden and Finland, and the ultimate cost to taxpayers is also expected to be large in Japan. Deposit insurance should not be implemented at all costs and it is one of the aims of the paper to measure the overall effect of deposit insurance on welfare and on economic growth.

Second, given the existence of externalities across banking networks, the full deregulation of banking markets may be one source of accumulation of excess capacities. As a consequence, in the countries that liberalised their banking sector, the shift away from regulation has never been fully complete, as indicated by the continuous reliance on prudential supervision based on licensing and ownership control, as well as risk management requirements. However, the authorities in charge of banking supervision have never received clear guidelines. The second aim of the paper is therefore to investigate under which circumstances it might be efficient, in order to maximise welfare and growth, to avoid that too many firms enter the market, or to facilitate the exit of banks from the market. A related question is how far one should promote bank mergers.

It is often argued that the risk of instability in the banking sector is only transitory in the case of a "regime shift" in the regulatory environment, which may trigger pricewars or lending mania, if one is willing to accept some myopia on the part of banks. But Canadian history offers an illustrative example where an oligopolistic banking 
system turned out to be more efficient (or less inefficient) than the U.S. system with respect to stability and consumers' welfare in the long run. During the period 19251980, interest rates paid on deposits were higher in Canada than in the US, and interest rates charged on loans were quite similar in the two countries (Bordo, Rockoff and Redish [1994]). No bank failure has been registered in Canada since 1924. By contrast, over 9000 failures of mostly small banks occurred in the US between 1930 and 1933. Although banks also benefitted from the absence of unit-banking regulation and the smaller size of the banking system allowed them to organise an implicit deposit insurance system, the main factor explaining the greater stability of the Canadian banking system is, according to Bordo, Rockoff and Redish [1996], that the Canadian federal government favored mergers and banking concentration during the period 19001925. Mergers are a substitute to bankruptcy which limits bankruptcy costs during times of financial distress. They also increase margins and lower the probability of bankruptcy for the subsequent periods. They helped banks to achieve their efficiency level as well as regional diversification and therefore to increase depositors' welfare. Hence, restrictions to entry may have improved welfare and achieved stability even in the absence of deposit insurance, as it was the case in Canada up to 1966 (Carr, Mathewson and Quickley [1995]). One should acknowledge, however, that both the U.S. and the Canadian banking systems where affected by two different inefficient regulations from 1925 to 1980 (namely deposit insurance and entry regulation), so that the Canadian experience may have not been so efficient in absolute terms. What is more, the U.S. banking system dramatically changed since 1980 (Berger, Kashyap and Scalise [1995]), and the Canadian banking system experienced severe difficulties at the same time.

The trade-off between competitive efficiency and stability of the banking sector has an impact not only on the cyclical behaviour, but also on the long run growth of an economy. Large (and possibly low frequency) macro-economic shocks may lead to a breakdown of the financial system, which affects the average growth rate over a decade or more. As detailed by Friedman and Schwartz [1963] and Bordo et al. [1996], the distrust of depositors and the recurrent bank runs over the period 18501925 in Canada and during the 1930s in the US may have had a long run negative impact on the efficiency of the collection of savings as households attempted to convert deposit into currency. ${ }^{1}$ As financial autarky generally implies a less efficient allocation of savings than intermediated savings, the lack of depositors' confidence due to the threat of a failure of the banking system may be detrimental to long run economic growth. Over the period starting from the last bank failure in Canada till the eve of World War II (1925-1938), the average annual growth of GDP per head in Canada was more than half a percentage point higher than the growth rate in the United States, where a breakdown of the financial system happened during the Great Depression. ${ }^{2}$

\footnotetext{
${ }^{1}$ This distrust of banks can be measured by the ratio of cash/deposits which exhibit a negative correlation with growth rates (Friedman and Schwartz [1963]).

${ }^{2}$ Authors' calculations based on data from Maddison [1995], p.206-209.
} 
Nowadays, in several less developed countries, depositors' lack of confidence in the financial system is an acute problem which inhibits the collection of savings and may contribute to the persistence of poverty traps (Fry [1995]). The present paper tackles this general issue on the ground that the overall social cost of banks failures are higher than the costs of failures in other industries. This is due to the existence of negative externalities among banks and companies, leading to systemic risk. ${ }^{3}$

Section 2 presents a sketch of the model and of its core assumptions. Section 3 of the article describes the behaviour of firms, households and financial intermediaries, including the equilibrium with free entry. Section 4 analyses the possible growth paths. Section 5 considers the impact of deposit insurance on welfare. The effects of reducing excess capacities in the banking system is assessed in section 6 . A last section concludes briefly the paper.

\section{The model}

\subsection{A Sketch of the Model and Its Results}

This model includes five market imperfections. It is necessary to emphasize which kind of results are driven by each of them and by their interaction.

First of all, we assume that there is imperfect competition with horizontal differentiation on the deposit market as in Salop's [1979] model. ${ }^{4}$ Such a model allows to assess easily the impact on banking markets of shifts in depositors' confidence. Households choose between deposits or an alternative "storage technology", so that distrust in the banking system affects the ratio between deposit and the storage technology, in a similar way as the fluctuations in the deposit/currency ratio analyzed by Friedman and Schwartz [1965]. ${ }^{5}$

The second core assumption of our model is the introduction of bankruptcy costs for each operating bank. As soon as there are deadweight losses from bankruptcy costs, the expected welfare of the economy is affected, which is not the case with perfect financial markets. As we intend to study the financing of deposit insurance and the management of systemic risk, we consider that all banks are identically affected by a macro-economic shock, which may generate a sizeable bankruptcy cost in the overall

\footnotetext{
${ }^{3}$ Loss rates defined as the ratio of total losses ultimately experienced by depositors of the failing banks in a given year to total deposits during that year were higher than $40 \%$ in Canada for 4 out of 65 years between 1880 and 1925 (Bordo et al.[1996]). According to Gendreau and Prince [1986], direct costs of bankruptcy in large US banks during the 1929-1933 period amounted to $6 \%$ of liabilities and where higher than the costs of bankruptcy of non-financial firms. Regarding the issue of indirect failure costs, Rajan [1996] gives a measure of the value of relationships: in 1984, client firms of Continental Illinois Bank incurred average abnormal stock returns of $-4.2 \%$ during the bank's impending insolvency. See also Berger, Kashyap and Scalise's [1995] calculations.

${ }^{4}$ Horizontal differentiation among banks on the deposit market is related to the fact that banks differ in terms of location, range of services offered and pattern of relationships with customers.

${ }^{5}$ This storage technology could be modelled as currency, with its supply growing exogenously, as in Williamson [1987].
} 
banking sector, and therefore may present a large negative effect on expected aggregate welfare, even when the bankruptcy probability is low.

On the basis of these two distortions alone, namely imperfect competition in banking together with the assumption of bankruptcy costs for banks, a trade-off may appear between competition and stability. Increasing competition has two opposing effects. On the one hand, it increases the posted return on deposits through the elimination of the usual deadweight loss associated to imperfect competition (see e.g. Berger and Hannan [1998]). On the other hand, it decreases banks' expected profits, partly because it increases the probability of bankruptcy in the face of a macro-economic shock and thus lowers expected return for depositors who bear the deadweight loss related to bankruptcy costs. To exhibit this trade-off, it is therefore not necessary to consider shifts in the risk-diversified portfolio of banks. It is well known that in this latter case too, increasing competition may give incentives to bankers toward excessive risktaking through portfolio changes in an effort to maintain the level of expected profits obtained in the presence of lower competition (Keeley [1990], Chan et al.[1992]). But we stress here that the assumption of the excessive risk taking within risk-diversified portfolios is not indispensable in order to have a stability/competition trade-off. ${ }^{6}$

Third, we introduce asymmetric information between depositors and banks, in line with the recent economic literature on bank runs which focused naturally on the role of depositors expectations and of asymmetric information theories of financial intermediation. Following Diamond [1984], we abstract from limited liability issues. ${ }^{7}$ Incentives to banks are provided by the existence of nonpecuniary penalties, so that the free put option of deposit insurance does not generate perverse incentives to go bankrupt. As mentioned before, depositors bear the cost of bankruptcy. We consider a Bayesian rational expectation equilibria to model depositors expectations about failure probabilities, as in Matutes and Vives' [1996] duopoly model. The presence of scale economies in the banking sector, due to the existence of a minimum size investment, leads to the possible occurence of a banking crisis equilibrium, related to a coordination failure between depositors expectations, like a sunspot (Matutes and Vives [1996]). In the other equilibria, the probability of default is endogenous and depends on fundamentals due to the rational expectation assumption. ${ }^{8}$

\footnotetext{
${ }^{6}$ We do not focus on the countervailing incentive of the bank charter value put forward in e.g. Bhattacharya et al. [1998]. In a dynamic setting, the present value of expected future rents represent the bank's charter value. If the deposit insurer threatens to close the bank whenever it fails, then a high bank charter value can deter risk taking. The higher the bank charter value (the higher the bank market power), the higher the cost associated with losing it (Marcus [1984], Keeley [1990], Suarez [1998]). But, as put forward by Bhattacharya et al.'s [1998] survey, "most of the models are partial equilibrium and do not completely endogenize bank rents", by contrast with this paper.

${ }^{7}$ Analysis of the choice of asset risk and the moral hazard problem associated with excessive risk taking under limited liability can be found in Genotte and Pyle [1990], John, John and Senbet [1991], Besanko and Thakor [1992] and Matutes and Vives [2000].

${ }^{8}$ Besanko and Thakor [1992] study the effects of barriers to entry in the banking sector in a partial equilibrium model. An innovation of our model is to endogeneise the probability of bank failures, whereas this is an exogenous parameter in their model.
} 
Fourth, we consider a general equilibrium model with overlapping generations and production (Diamond [1965]). Overlapping generations models include a market imperfection as dead generations cannot trade with the generations following their death. However, the current literature on deposit insurance stresses even more restrictive partial equilibrium models. These models cannot evaluate the costs and the availibility of funds necessary to finance deposit insurance. Funds are most of the time considered to be unlimited and available at zero costs. In our model, government provides funds through intergenerational transfers. The availability of funds for deposit insurance is thus endogenous in our setting.

Finally, we consider the possibility of an endogenous growth mechanism based on external increasing returns to scale as in Romer [1986]. The reason why we introduced this market distortion is that we note that stability problems of the banking sector may have severe long-term consequences by lowering the average growth rate of the economy. The production externality in the production sector is somehow related to coordination issues. Its effect in our model is to amplify the consequences of the other capital market imperfections through a long run growth rate effect. We also provide the results without the assumption of external increasing return to scale. Then, one obtains the standard effect on the transitory growth rate of Diamond's [1965] model without production externality but with an exogenous long run growth rate.

These market imperfections call for policy measures related to prudential supervision. We compare here restrictions on competition, and in particular on entry, for instance of foreign banks or out of state banks in the US (Mishkin [2000]), ${ }^{9}$ to the existence of a deposit insurance scheme when there is free entry in the banking sector. We assess the impact of these two policy measures in terms of feasibility and welfare enhancing properties.

The benchmark case of free entry in the banking industry represents the most competitive outcome in the context of imperfect competition (monopolistic competition). ${ }^{10}$ Banking structure is in this case endogenous, the equilibrium number of banks being the consequence of the existence of a fixed cost in the banking activity, which is akin to assuming increasing returns in financial intermediation (see e.g. Besanko and Thakor $[1992 \mathrm{a}]) .^{11}$

Comparing the two prudential policies leads to the three following results. First, deposit insurance eliminates default and therefore it is able to eliminate confidence crises related to the problem of coordination on expectations. It is not the case for the restriction to entry, where default remains a possibility. But, second, deposit insurance cannot always be financed by intergenerational tranfer, when the standard error on the macro-economic risk exceeds a threshold that we determine (in terms of

\footnotetext{
${ }^{9}$ Or by imposing ceilings on interest rate charged on deposits.

${ }^{10}$ Free entry is usually related to a long run equilibrium, which is compatible with studying long-run growth, as we do in this model.

${ }^{11}$ The fixed intermediation cost plays also a role in the existence of coordination failures of depositors expectations.
} 
mean-preserving spread). Conversely, restrictions to entry can always be implemented. When there is no confidence crisis, however, one can compare welfare between the two policies. On the deposit insurance side, we show that organizing an ex post intergenerational transfer from young workers to old savers, i.e. only once a bad shock hits the economy, is better for saving, growth and welfare than attracting a large amount of liquid funds ex ante from young workers to insure them, as it diverts too much savings from productive activities. ${ }^{12}$ Concerning restrictions to entry, we show that they improve welfare only under a particular condition. This is the case when a slight change of interest rate implies a rather large change in the probability of bankruptcy, i.e. when the distribution of the macro-economic risk is concentrated in the neighborhood of the free entry interest rate. However, in a context where deposit insurance can be implemented while free entry does not maximize welfare, we show that the introduction of deposit insurance with free entry can provide a higher welfare. The overall conclusion is rather at the advantage of deposit insurance with free entry with respect to entry restrictions. But, when deposit insurance with free entry cannot be financed, there remains a possibility that restricting entry may improve welfare in some cases.

We now present the model in fuller details.

\subsection{Firms}

The technology exhibits constant returns to scale with respect to capital $k_{t}$ and labour $N$ and the production function has a Cobb-Douglas specification. Capital entirely depreciates in one period. Population $N$ is constant over time. We have $y_{t}=u_{t} a_{t} k_{t}^{\alpha} N^{1-\alpha}$, where $u_{t}$ represents a macro-economic shock affecting technology, which cannot be diversified. It is identically and independently distributed on $[\underline{u}, \bar{u}]$ from period to period, with an expectation equal to unity $\left(E_{t-1}\left[u_{t}\right]=1\right)$.

Aggregate output is denoted $Y_{t}$. This simple specification of the technology can be understood as a reduced form of more complex endogenous growth models. Firms are price takers on the final good market. At date $t-1$, entrepreneurs choose capital and labour for production at date $t$ by maximizing expected profits, taking into account the expectation of the macroeconomic shock $u_{t}$ that will hit the economy next period:

$$
\left(N^{*}, k_{t}^{*}\right) \in \operatorname{ArgMax} E_{t-1}\left[u_{t} a_{t} k_{t}^{\alpha} N^{1-\alpha}-w_{t} N-R_{t} k_{t}\right]
$$

Wage earners' expected income is $E_{t-1}\left[w_{t}\right]$, and the expected return on capital is $E_{t-1}\left[R_{t}\right]$. labour market is perfectly competitive. Ex ante factor demands are functions of marginal productivities:

$$
E_{t-1}\left[R_{t}\right]=a_{t} \alpha k_{t}^{\alpha-1} N^{1-\alpha}
$$

\footnotetext{
${ }^{12}$ For example, Qi [1994, p.406] only considered as a possibility for the government to sponsor a lender of last resort financed by attracting ex ante liquid funds of depositors in his overlapping generation model version of the Diamond and Dybvig's [1983] model.
} 


$$
E_{t-1}\left[w_{t}\right]=a_{t}(1-\alpha) k_{t}^{\alpha} N^{-\alpha}
$$

Once the shock is realised, wage and the return on capital are determined by realised marginal productivities:

$$
\begin{aligned}
R_{t} & =u_{t} a_{t} \alpha k_{t}^{\alpha-1} N^{1-\alpha} \\
w_{t} & =u_{t} a_{t}(1-\alpha) k_{t}^{\alpha} N^{-\alpha}=\frac{1-\alpha}{\alpha} R_{t} \frac{k_{t}}{N}
\end{aligned}
$$

We provide results for this production function and also we consider the particular case of endogenous growth, when the productivity term $a$ introduces a positive externality, depending on aggregate private capital $K_{t}$ as in Romer [1986], so that $a_{t}=A K_{t}^{1-\alpha}$.

\subsection{Households' behaviour}

A simple model of overlapping generations is considered. The population of each generation is of fixed size and lives for two periods. The welfare of future generations is not taken into account in the agent's utility function. The population is a continuum of mass $N$ spread on a circle of length 1 in order to formalize spatial differentiation. In the first period, each agent offers one unit of labour and saves a fraction of her income. The utility function depends on each period's consumption in a linear fashion, so that households are risk neutral. ${ }^{13}$ Households have no direct access to financial markets, and they cannot set up a business by themselves. They decide upon the amount of savings $S_{t}$ and its allocation between a riskless asset $\left(1-b_{t}\right)$ and a risky asset $\left(b_{t}\right)$, taking into account the expected net return of each asset.

$$
\left(S_{t}, b_{t}\right) \in \operatorname{Arg} \max \left(w_{t}-S_{t}\right)+\frac{E_{t}\left[b_{t} \cdot\left(R_{t+1}^{I F}-\delta \cdot l\right)+\left(1-b_{t}\right) \cdot v\right] S_{t}}{1+\rho}
$$

$w$ is the real wage, $\rho$ is the subjective rate of time preference, $v$ is the riskless asset's return, $R_{t+1}^{I F}$ is the random return of a deposit with a financial intermediary. In order to make such a deposit, agents face a 'transport' cost which is expressed as a linear function of the distance $l$ between the financial intermediary and the agent, with a fixed distance coefficient $\delta$. This hypothesis represents the effects of horizontal differentiation between financial intermediaries. Various interpretations of this effect can be given. There is an opportunity cost of time spent to go to the bank. More fundamentally, financial intermediaries differentiate themselves by the nature of services offered to depositors, such as the size of their automated teller machines (ATM) networks, the possibilities for consumption credit, the quality of service, etc. Differentiation is taken here as given. The horizontal differentiation representation is similar to that in Salop [1979]: $n$ financial intermediaries are located at a distance $1 / n$ of each other

\footnotetext{
${ }^{13} \mathrm{~A}$ mimimum consumption level constraint can be included.
} 
on the circle where households are uniformly distributed. Given the utility function specified above, an agent will save all her income if the expected return on savings is larger than the rate of time preference, i.e. if $\max \left[v, E_{t}\left(R_{t+1}^{I F}\right)-\delta \cdot l\right]>1+\rho$; this condition is assumed to hold. The individual propensity to save does not depend on the interest rate $\left(S_{t}=w_{t}\right)$.

We proceed in two steps. First, in the following subsection, we determine equilibria for a given number of banks. In subsection 2.4., we allow for free entry to pin down the number of banks.

\subsection{Oligopolistic Banking Equilibria without Entry}

The equilibrium sequence follows broadly the one applied by Matutes and Vives [1996, p.189] in their duopoly model with horizontal differentiation, which they also described as the perfect Bayesian equilibria of a game with Bayesian depositors having point prior beliefs. At date $t$, depositors are endowed with ex ante identical and prior beliefs about the probability to have the principal and interests on deposits actually being paid back by any bank. This identical probability of success for banks is denoted $p_{t}$. It describes an instantaneous and perfect correlation between banks failures as well as between depositors expectations, which may happen during depositors panics. We retained the assumption of symmetrical beliefs as we intend to stress the confidence in the intermediation sector as a whole. This model of systemic risk is not an explicit model of bank contagion, but, rather, a model of bank failures driven by systematic shocks.

We describe, first, the relationships between banks and companies, then, between banks and depositors.

We assume that banks can invest in productive projects, without asymmetric information. ${ }^{14}$ Macroeconomic risk cannot be diversified away, and is entirely borne by banks, which are the only suppliers of capital. Therefore, $R_{t+1}$ is the random return at $t+1$ per unit of capital invested by a bank. In addition each bank $i$ faces at $t+1$ a fixed cost of intermediation $C_{t+1}$.

We assume that households cannot observe ex post (at $t+1)$ banks' return from lending. This hypothesis of an infinite cost of monitoring allows us to introduce Diamond's [1984] framework so that optimal deposit contracts are standard debt contracts. Households only know the probability distribution of the ex ante return . A bank $i$ offers an interest rate on deposits $r_{i, t}$ and incurs an endogenous non-pecuniary bankruptcy cost, as in Diamond [1984]. ${ }^{15}$ This bankruptcy cost corresponds to the

\footnotetext{
${ }^{14}$ As Modigliani and Miller's theorem applies to the credit market, any kind of financial contract contingent on ex post state realisation can be chosen, as long as the reservation level of profits of firms or of financial intermediaries is satisfied. For simplicity, we assumed that the contract between banks and firms specifies ex post state contingent returns. Nonetheless, an intermediary margin on the expected return is taken ex ante by banks when supplying funds to firms.

${ }^{15}$ Formally, the optimal contract is such that the bank incurs an endogenous non-pecuniary penalty so that it is indifferent to pay back a constant deposit rate $r_{i}$ to depositors. If it decides to reimburse
} 
time spent by intermediaries in justifying the low return, the cost of finding a new management for the bank, or it can be associated to the loss of reputation. If the bank's income cannot repay the debt, bankruptcy is declared. In this case, we suppose that the remaining value of the bank is not paid back to depositors but lost in bankruptcy costs borne by depositors, as in Matutes and Vives [1996]. Households expect to lose their deposits with a probability $1-p_{t}$, so that the ex ante expected return on deposits is given by $E_{t}\left[R_{t+1}^{I F}\right]=p_{t} r_{i, t} \cdot{ }^{16}$ Banks are aware of households' expectations and determine the rate of interest on deposits accordingly. Households then decide to deposit their savings in the nearest bank, if the expected return net of transport cost exceeds $v$, the return on the storage technology $\left(p_{t} \cdot r_{i, t}-\delta \cdot l \geq v\right)$. Financial intermediaries may collect the savings from all depositors, or from some of them, or none at all. If a sufficient amount of savings has been collected by banks, they lend to firms and pay operating costs. In equilibrium, households' expectations are rational, so that the probability of success is equal to the probability of positive profits of banks. The interaction between this probability of success and the deposit rate defines the equilibria for a given number of banks.

In the event of success, banks repay depositors in the second period and consume the remaining surplus. In the event of failure of the banking system, depositors (who now belong to the old generation) and banks receive no income. The younger generation also faces risky wages.

Before computing the optimal program for a banker's decision, we specify the demand for deposit for a given bank $i$. We consider here an equilibrium with an incomplete collection of savings. Banks do not compete directly on the deposit market, a situation we can label as "pure" local monopolies. ${ }^{17}$ Therefore, we assume that the equilibrium number of banks $\left(n_{t}\right)$ is such that the distance between two banks is always strictly larger than $2 l_{i, t}$, where $l_{i, t}$ is the distance between the marginal depositor and the nearest bank $i\left(2 l_{i, t} \leq \frac{1}{n_{t}}\right)$. Depositors' expectations are supposed to be such that $p_{t} \cdot r_{i, t}>v$, so that some households deposit in banks. The marginal lender is indifferent between putting her saving in the bank and storing it. Its distance to the nearest bank is given by:

$$
l_{i, t}=\frac{p_{t} \cdot r_{i, t}-v}{\delta}
$$

Deposits with bank $i$ are then $2 l_{i, t}$ times the amount of individual saving. Taking account of the number of depositors $N$, the amount $d_{i, t}$ deposited with bank $i$ is equal to:

$$
d_{i, t}=2 N l_{i, t} w_{t}
$$

at an inferior rate $z$, the bank will incur a penalty $\phi(z)=\max \left(r_{i}-z, 0\right)$.

${ }^{16}$ An alternative model where banks can influence depositors' expectations with their choice of the rate of interest on deposits is possible but would lead to complications we wish to avoid here.

${ }^{17}$ The equilibrium with touching markets is available from the authors upon request. 
Intermediated savings increase when the transport cost $\delta$, or when the return on the alternative asset $v$ decreases, or when the expected return on bank deposits $p_{t} r_{i, t}$ rises.

The presence of non-pecuniary externalities $\phi$ implies that risk neutral banks maximises expected profits unconditional to success (Diamond [1984]). The intermediation $\operatorname{cost} C_{t+1}$ in the banking industry requires a minimum size for deposits $d_{i, t}$ to operate. Bank $i$ lends to firms all their available funds in the risky projects $\left(k_{i, t+1}=d_{i, t}\right)$, because their return is higher than the return on the safe asset (the storage technology). Banks have no other mean of finance than deposits. We suppose that competition on the credit and deposit markets is imperfect and determined in a Cournot-Nash equilibrium with $n$ given players (banks). On the credit side, there is no horizontal differentiation but the elasticity of the demand for credit is the inverse of $1-\alpha \cdot{ }^{18}$ On the deposit side, there is horizontal differentiation but the elasticity of the demand for deposit is zero. Each bank solves the following problem:

$$
\begin{aligned}
\left(d_{i, t}, k_{i, t+1}\right) & \in \operatorname{Argmax} E_{t}\left[R_{i, t+1}\right] k_{i, t+1}-r_{i, t} d_{i, t}-C_{t+1} \\
\text { s.t. } k_{i, t+1} & =d_{i, t} \\
d_{i, t} & =2 \cdot N \cdot w_{t} \cdot p \cdot \frac{r_{i, t}-(v / p)}{\delta} \\
E_{t}\left[R_{i, t+1}\right] & =\alpha \cdot a \cdot k_{t+1}^{\alpha-1} \cdot N^{1-\alpha}
\end{aligned}
$$

This choice is made under a resource equilibrium constraint, taking into account the deposit demand for bank $i$ and the aggregate credit demand. One may notice that the probability of bankruptcy will appear in the marginal condition as a factor that raises the relative return of the riskless asset $v / p_{t}$.

The best response function of a bank gives the first order condition of the above program. As usually done, we only study symmetric equilibria, where the interest rates are the same for all banks. We therefore omit the index $i$ in what follows, as it is unnecessary. They are given by:

$$
r_{t}=\frac{\left(1+\frac{\alpha-1}{n}\right) E_{t}\left[R_{t+1}\right]+\frac{v}{p_{t}}}{2}
$$

The rate of interest on deposits is an average of the uncertainty-corrected return on the storage technology $\left(v / p_{t}\right)$ and of the credit interest rate less a mark-up depending on the elasticity of the firms' demand for funds $(1 /(\alpha-1))$ and the number of competing

\footnotetext{
${ }^{18}$ Mixing spatial differentiation and interest rate elasticity effects on the credit demand in general equilibrium leads to technical complications beyond to the scope of this paper (See Bensaïd and De Palma [1995, p.170] for a partial equilibrium study). Introducing Cournotian competition on the credit side gives room for the persistence of the incomplete collection of savings by banks with free entry, in a manner similar to Williamson [1987]. In the case of perfect competition on the credit market, free entry of banks fills "holes", i.e. new banks enters in areas where households do not deposit; therefore free entry equilibria are always of the "touching markets" variety.
} 
banks because of Cournotian competition in the credit market. A rise in the probability of success $p_{t}$, which measures households' confidence in the banking system, decreases the deposit rate and then increases the imperfect competition margin.

A rational expectation equilibrium imposes that households anticipate the actual probability of success:

$$
p_{t}=\operatorname{Pr}\left(R_{t+1} \cdot k_{t+1}-r_{t} \cdot d_{t}-C_{t+1} \geq 0\right)=1-F\left(r_{t}+\frac{C_{t+1}}{k_{t+1}}\right)
$$

We define $c_{t+1}=\frac{C_{t+1}}{k_{t+1}}$ as the ratio of the fixed cost with respect to deposit.

For a given number of banks, one needs to specify the distribution of risk in order to solve the system consisting of the two preceding equations. This determines the number of "short run equilibrium" values for the probability of success and the interest rate on deposits $\left(p_{t}^{*}, r_{t}^{*}\right)$. The amount of deposits collected by one bank $d_{t}^{*}$ and of credit $k_{t}^{*}$ can then be computed immediately. For a given number of banks and when deposit markets are not touching, several cases are possible: multiple equilibria, a unique equilibrium or none, as in Matutes and Vives [1996] duopoly model. Banks perceived as "low risk" by depositors will have, for a given interest rate, larger markets and hence a lower probability of default, which reinforces the initial confidence. Because of the fixed cost, a minimum size is required for any banking activity. There always exists an equilibrium without banks, which corresponds to a poverty trap for a zero probability of success of banks, where rational expectations are also self-fulfilling. Increasing returns in banking reinforce the possibility of multiple equilibria. One self-fulfilling mechanism may be characterised by the perception of a lower risk in banking by depositors, the increase in the intermediation margin and the decrease in the probability of bankruptcy associated with a bigger bank. But the standard monopolistic competition "long run equilibrium" with free entry exhibits a smaller set of equilibria as presented in the next section.

\subsection{Banking Equilibrium with Free Entry}

Knowing the equilibrium for a given number of banks $\left(p_{t}^{*}, r_{t}^{*}\right)$, we now suppose that there is free entry in the banking sector in the long run. The number of banks, $n_{t}^{* *}$, is determined by a zero profit condition. Ignoring the integer constraint, the zero profit condition for banks allows to pin down the number of banks, as:

$$
n_{t}^{* *}=\frac{(1-\alpha) E_{t}\left[R_{t+1}\right]}{2 c_{t}+\frac{v}{p_{t}^{* *}}-E_{t}\left[R_{t+1}\right]}=n^{*}\left(\begin{array}{c}
E_{t}\left[R_{t+1}\right], \underset{+}{p_{t}^{* *}}, \underset{-}{v}, c_{t+1} \\
-t_{-}
\end{array}\right)
$$

A decrease in marginal productivity for the final good sector and a rise in the intermediation cost or in the relative return of the alternative asset diminish the number of banks and aggravate imperfect competition. This new equation is to be added to the system of the preceding section in order to solve the long run equilibrium 
with free entry $\left(p_{t}^{* *}, r_{t}^{* *}, n_{t}^{* *}\right)$ (the ${ }^{* *}$ superscripts refer to equilibrium values with free entry). For $p \in] 0,1]$ :

$$
\begin{aligned}
& r_{t}^{* *}=E_{t}\left[R_{t+1}\right]-c_{t+1} \\
& p_{t}^{* *}=1-F\left(E_{t}\left[R_{t+1}\right]\right)
\end{aligned}
$$

The zero expected profit condition (where profit is a linear function of the shock) imposes that the probability of negative profit should be equal to the probability that the ex post return equals its expectation. When the random variable is symmetrically distributed, the usual free entry condition implies a rather high probability of default, equal to $1 / 2$. As a consequence, whatever the ex ante expectation on the default probability $\left.\left.p_{t} \in\right] 0,1\right]$, banks' behaviour and the free entry condition will determine ex post a probability of success $p_{t}^{* *}$. Apart from the "distrust" equilibrium $\left(p_{t}=\right.$ $0 \Rightarrow p_{t}^{* *}=0$ ), there exists only one other long-run equilibrium, defined by the above equations. The condition for a partial collection of deposit with respect to the full collection over the whole circle is given by $2 l_{t}^{* *} n_{t}^{* *}<1$ with $l_{t}^{* *}=\frac{p_{t}^{* *} r_{t}^{* *}-v}{\delta}$. ${ }^{19}$

\section{Three growth regimes}

Under the previous assumptions regarding the non-availability of other sources of funding outside banks and the total depreciation of capital in one period, the capital stock is equal to investment in that period, as well as to intermediated savings. Three regimes are possible. A first equilibrium corresponds to the absence of banks and therefore to the non-intermediation of savings. Investment is null and the growth rate is zero. This defines a poverty trap. In the second type of equilibrium banks collect deposits as local monopolies. A third equilibrium is characterized by total intermediation of aggregate saving, which corresponds to the intermediation of all aggregate saving and to a maximum growth rate. We normalize the population size to unity $(N=1)$ :

- The poverty trap

It may come from households' distrust towards the banking sector. If agents expect a probability of success $p_{t}=0$, the zero growth equilibrium appears whatever the levels of expected productivity for firms and the levels of intermediation cost. The self-fulfilling prophecy mechanism is the following. Depositors have an anticipation of a zero probability of success. As a consequence, nobody will make deposits to the banks, whatever the interest rate offered. The amount of intermediated saving is null, and no bank can operate. Since intermediation is necessary for investment, there is no growth.

\footnotetext{
${ }^{19}$ The case of full collection of savings is available from the authors upon request.
} 
A second possibility of a poverty trap exists, when markets are non touching. The condition is not so much based on expectations, but rather, on technology. When $l_{t}^{* *} \leq 0$, the productivity factor $E_{t}\left[R_{t+1}\right]$ is not high enough to have agents go to the bank considering the level of intermediation costs and the default risk: $E_{t}\left[R_{t+1}\right]<c_{t+1}+\left(v / p_{t}^{* *}\right)$. No bank is active and growth is zero.

\section{- Local monopolies}

Local monopolies obtain when $0<2 n_{t}^{* *} l_{t}^{* *}<1$ and $n^{* *}>0$. This supposes that capital productivity $E_{t}\left[R_{t+1}\right]$ is such that

$$
v / p_{t}^{* *}+c_{t+1}<E_{t}\left[R_{t+1}\right]<\min \left[v / p_{t}^{* *}+2 c_{t+1}, h\left(c_{t+1}, v / p_{t}^{* *}\right)\right] .
$$

There is complete collection of saving when $l^{* *}=1 / 2 n^{* *}$, which sets a higher bound to capital productivity $E_{t}\left[R_{t+1}\right]<h\left(c_{t}, v / p^{* *}\right)$ so that the deposit markets for each bank are not "touching" ${ }^{20}$. The existence of a long term equilibrium where aggregate saving is not entirely intermediated by banks is made possible by imperfect competition in banking activity. Without it, a bank could always enter and take control of the market share left by other banks, until all banks are in competition for the marginal saver (this is what happens when markets are touching). When markets are not touching, and for a given number of bank, the random growth factor is given by this general expression $\left(K_{t}\right.$ denotes aggregate capital):

$$
G_{t}=\frac{K_{t+1}}{K_{t}}=\frac{n_{t} 2 l_{t}^{*}}{L} \frac{w_{t} N}{K_{t}}=\frac{n_{t} \frac{2\left(p_{t}^{*} r_{t}^{*}-v\right)}{\delta}}{L} \frac{w_{t} N}{K_{t}}
$$

$w_{t}$ is individual savings, $w_{t} N$ is aggregate savings. Financial intermediation determines the growth rate through the number of banks $n$ and the market share of each bank measured by $2 l^{*}$ (the latter measures intermediated savings) relative to the overall potential deposit market measured by the length of the circle $L$.

In the particular case of endogenous growth, the expected aggregate return to capital takes into account the productive externality and is constant and the real wage are given by :

$$
\begin{aligned}
E_{t}\left[R_{t+1}\right] & =\alpha A \\
w_{t} & =u_{t}(1-\alpha) A K_{t}=u_{t}\left(\frac{1-\alpha}{\alpha}\right) E_{t-1}\left[R_{t}\right] K_{t}
\end{aligned}
$$

\footnotetext{
${ }^{20}$ Developments related to "touching" markets are available from the authors.
} 
- With free entry in banking and population normalized to one, the growth factor is now equal to:

$$
\begin{aligned}
G_{t} & =u_{t} A(1-\alpha) \cdot 2 \frac{[1-F(A \alpha)]\left(A \alpha-c_{t+1}\right)-v}{\delta L} \cdot \frac{A \alpha(1-\alpha)}{2 c_{t+1}+\frac{v}{1-F(A \cdot \alpha)}-A \alpha} \\
& =G_{t}\left(\begin{array}{c}
A, \delta, c_{t+1}, \underline{v}, p_{+}^{* *}, \underset{?}{\alpha} \\
+-c_{-}
\end{array}\right)
\end{aligned}
$$

The growth rate is constant. As in all "AK" endogenous growth model, it depends positively on capital productivity. Imperfect competition in the banking sector introduces three explanatory factors: population density $(1 / L)$, intermediation cost ratio $c_{t}$ and $v / p^{* *}$, the return on the alternative asset, augmented by the risk of a failure of the banking system. The intermediation cost ratio is determined by the following implicit equation:

$$
c_{t+1}=\frac{C_{t+1}}{2 l_{t}^{* *} w_{t}}
$$

where $l_{t}^{* *}=l_{t}^{* *}\left(c_{t+1}\right)$ and where the intermediation cost $C_{t+1}$ is given.

It is useful to assess the relationship between welfare and growth in each of these regimes. There are four sources of inefficiency in this model. First, there is the distortion due to imperfect competition in the banking sector, which affects the level of saving and investment. Second, there is the deadweight loss of bankruptcy costs borne by depositors. Third, there is the lack of intergenerational exchange, which appears in overlapping generation models when the utility of finitely lived agents does not include bequests. Fourth, there is the productive externality in the production function which introduces a wedge between the social and private returns to investment.

A measure of welfare for a population of heterogenous agents (with respect to the return they obtain on their savings, which depends on their location) is to sum over the individual utilities for a representative generation. ${ }^{21}$ Households save their whole income in the first period. The return on savings depends on the transaction cost they incur. Noting $U_{t}^{a}$ the sum of individual (expected) utilities of households born on date $t-1$, dividing by the capital stock of the first period, and substituting $\delta \cdot l^{*}=p^{*} r^{*}-v$ , one obtains the following general relationship between welfare (normalised by capital $K_{t}$ ) and growth for an exogenous or endogenous number of banks:

$$
\begin{aligned}
\frac{U_{t}^{a}}{K_{t}} & =\frac{1}{1+\rho} \frac{w_{t}}{K_{t}} 2 n_{t}\left\{\int_{0}^{l_{t}^{*}}\left[p_{t}^{*} r_{t}^{*}-\delta \cdot i\right] d i+\int_{l_{t}^{*}}^{1 /\left(2 \cdot n_{t}\right)}[v] d i\right\} \\
& =\frac{1}{(1+\rho)} \frac{G_{t}}{l_{t}^{*}}\left[p_{t}^{*} r_{t}^{*} l_{t}^{*}-\delta \frac{\left(l_{t}^{*}\right)^{2}}{2}+v\left(\frac{1}{2 n_{t}}-l_{t}^{*}\right)\right]
\end{aligned}
$$

\footnotetext{
${ }^{21}$ This measure of welfare does not resolve the overlapping generation distortion.
} 


$$
\begin{aligned}
& =\frac{G_{t}}{(1+\rho)}\left\{p_{t}^{*} r_{t}^{*}-\frac{p_{t}^{*} r_{t}^{*}-v}{2}+v \cdot\left(\frac{w_{t}}{G_{t} K_{t}}-1\right)\right\} \\
& =\frac{1}{(1+\rho)}\left[\left(\frac{p_{t}^{*} r_{t}^{*}-v}{2}\right) G_{t}+v \frac{w_{t}}{K_{t}}\right]
\end{aligned}
$$

As welfare is a linear function of the real wages, it is a linear function of the macroeconomic shock $u_{t}$. This measure of welfare does not take into account the risk of a confidence crisis $(p=0)$, where savings and welfare turn to be zero, with a low but unknown probability.

\section{- Complete collection of saving}

There is complete collection of saving when $l^{* *}=1 / 2 n^{* *}$, which sets a lower bound to capital productivity $E_{t}\left[R_{t+1}\right]>h\left(c_{t}, v / p^{* *}\right)$. Since all saving is collected, the savinginvestment equality gives the following growth rate: $G_{t}=\frac{w_{t}}{K_{t}}$. In the case of endogenous growth, this growth rate is such that $G_{t}=u_{t}(1-\alpha) A$. Since the individual saving behaviour does not depend on interest rates, neither does aggregate collected saving and growth when markets are touching. ${ }^{22}$ But imperfect competition affects the returns on savings and the general expression of welfare, for an exogenous or endogenous number of banks $n_{t}$ :

$$
\begin{aligned}
\frac{U_{t}^{a}}{K_{t}} & =\frac{1}{1+\rho} \frac{w_{t}}{K_{t}} 2 n_{t}\left(\int_{0}^{1 / 2 \cdot n_{t}}\left[p_{t}^{*} r_{t}^{*}-\delta \cdot i\right] d i\right)=\frac{G_{t}}{(1+\rho)} 2 n_{t}\left(\frac{p_{t}^{*} r_{t}^{*}}{2 n_{t}}-\delta \frac{\left(\frac{1}{2 n_{t}}\right)^{2}}{2}\right) \\
& =\frac{G_{t}}{(1+\rho)}\left(p_{t}^{*} r_{t}^{*}-\frac{1}{4} \frac{\delta}{n_{t}}\right)
\end{aligned}
$$

The relationship between welfare depends on the returns on savings whereas growth is independent of these returns.

\section{Deposit insurance}

One possible way to increase welfare is to introduce deposit insurance with free entry in order to eliminate systemic risk (a simultaneous default of all the banks represents systemic risk in our setting). As indicated in the preceding section, there are two types of free entry equilibria, corresponding to two types of ex-ante expectations of depositors of the probability of default. On the one hand, a self-fulfilling confidence crisis (possibly driven by a sunspot) is such that $p_{t}=0 \Rightarrow p_{t}^{* *}=0$. On the other hand, a perfect-foresight equilibrium is characterised by $\left.\left.p_{t} \in\right] 0,1\right] \Rightarrow p_{t}^{* *}=1-F\left(E_{t}\left[R_{t+1}\right]\right)$.

\footnotetext{
${ }^{22}$ The effect on growth of a mark down of financial intermediaries on savings of a representative household whose savings behaviour depends positively on the interest rate on deposit has already been dealt with in several papers (see, for example, Berthélémy and Varoudakis [1996]). In this paper, we stress another effect. Households are heterogenous, so that intermediated savings is a function of the number of depositors. The two effects can be mixed, if one assumes that individual savings function depends on interest rate, but our point would be less clear.
} 
We consider the case of deposit insurance with free entry (it is shown in the next section that full deposit insurance with restrictions to entry is less efficient). We investigate here the case of a deposit insurance fund, which ensures that depositors are paid back with certainty in the case of failure of the bank, whatever the size of the losses of the banks (when $R_{t+1} \leq E_{t}\left[R_{t+1}\right]$ in the case of free entry in the banking industry). The probability of success of banks is equal to one in that case. Diamond's [1984] non pecuniary penalties are maintained so that a banker has no incentive to declare a bad state of nature to increase its personal profits, even with a safety net.

When it is necessary to avoid rapidly the risk of a breakdown of the banking system, wage earners in the young generation have generally to contribute for old savers. The first full deposit insurance of systemic risk scheme that we consider is as follows. The deposit insurance fund decide to tax the young generation only once the macro-economic shock is known and if banks are facing bankruptcy to make up for the difference between the realized value of $R$ and the promised value of $r$. Taxation implies that the fund be run by the government. The deposit insurance fund is a "pay-as-you-go" system, designed to ensure that the "old" generation receives $r$ with certainty. In other words, we require premia paid to the deposit insurance fund to be fair and no other resources to be made available to the government, which only organises the eventual transfer between generations. However, such a deposit insurance may face a limit on the availability of funds.

Proposition 1. Feasibility of deposit insurance :

Full deposit insurance is possible only if the lower bound of the macroeconomic return $u_{-}$is above a threshold $u_{t}^{I}$ which depends positively on the elasticity of capital with respect to production, and negatively on the ratio of the fixed cost in banking to expected profit flows $\frac{c_{t}}{E_{t}\left[R_{t+1}\right]}=\frac{C_{t}}{E_{t}\left[R_{t+1}\right] k_{t}}$. Otherwise, only an incomplete deposit insurance scheme can be implemented, where states of nature for large negative macroeconomic shocks (such that $u \leq u_{t}<u_{t}^{I}$ ) cannot be insured.

With free entry, the zero expected profit condition leads to an identical value of the posted deposit interest rate with or without deposit insurance $\left(r_{t-1}^{I *}=r_{t-1}^{* *}=\right.$ $\left.E_{t-1}\left(R_{t}\right)-c_{t}\right)$. Still with free entry, the young generation has therefore to make up for the difference $r_{t-1}^{* *}-R_{t}=E_{t-1}\left[R_{t}\right]-c_{t}-R_{t}$ through the deposit insurance fund, when banks are going bankrupt, i.e. for $R_{t}<E_{t-1}\left[R_{t}\right]$. Let $D_{t-1}=K_{t}$ be aggregate deposits of the old. Obviously, the tax proceeds are bounded by the aggregate income of the young generation (if $R_{t}<E_{t-1}\left[R_{t}\right]$, the macro-economic shock lies between $\left.0<u \leq u_{t}<1\right)$ :

$$
\begin{aligned}
\left(E_{t-1}\left[R_{t}\right]-c_{t}-u_{t} E_{t-1}\left[R_{t}\right]\right) D_{t-1} & \leq w_{t}=u_{t}\left(\frac{1-\alpha}{\alpha}\right) E_{t-1}\left[R_{t}\right] K_{t} \Rightarrow \\
\left(1-\frac{c_{t}}{E_{t-1}\left[R_{t}\right]}\right) \alpha & =u_{t}^{I} \leq u_{t} \quad \forall u_{t} \in[u, 1]
\end{aligned}
$$


Full deposit insurance is possible only if the lower bound of the macroeconomic return $\underline{u}_{-}$is not below the left hand side of the previous equation, otherwise depositors are not insured against all the states of nature. This lower bound on the macroeconomic return is such that:

(i) it increases with the elasticity of capital with respect to output, or the share of the return to capital in total income, which has to be insured.

(ii) it decreases with the wedge between the fixed cost and the return on savings $\frac{c_{t}}{E_{t}\left[R_{t+1}\right]}=\frac{C_{t}}{E_{t}\left[R_{t+1}\right] k_{t}}$. It measures also the difference between the deposit rate and the expected credit return. The higher it is, the lower the deposit rate and the lower the amount of funds to be insured.

Assuming that this condition is fulfilled, we determine the growth rate and the expected welfare in the case of deposit insurance with free entry. First, in the case when the proportion of depositors is below unity (i. e. markets are not touching) and with free entry, aggregate collected saving with deposit insurance provides the expression of the growth factor with deposit insurance and free entry $G_{t}^{I}$ as it is equal to investment of the next period:

$$
G_{t}^{I}=\frac{K_{t+1}}{K_{t}}=\frac{1}{K_{t}} \frac{2 l_{t}^{I *} n_{t}^{I *}}{L}\left\{w_{t}-D_{t-1} \cdot \mathbf{1}_{\left\{R_{t}<E_{t-1}\left(R_{t}\right)\right\}} \cdot\left[E_{t-1}\left(R_{t}\right)-c_{t}-R_{t}\right]\right\}
$$

where $\mathbf{1}_{\left\{R_{t}<E_{t-1}\left(R_{t}\right)\right\}}$ equals 1 when $R_{t}<E_{t-1}\left(R_{t}\right)$, and 0 otherwise, $2 l_{t}^{I *}$ is the market share of each bank with deposit insurance and free entry and $n_{t}^{I *}$ is the number of banks with deposit insurance and free entry. The market share of a bank is larger with deposit insurance than without:

$$
2 l_{t}^{I *}=2 \frac{r_{t}^{I *}-v}{\delta}=2 \frac{r_{t}^{* *}-v}{\delta} \geq 2 l_{t}^{* *}=2 \frac{p_{t}^{* *} r_{t}^{* *}-v}{\delta}
$$

The number of banks is higher with deposit insurance than without:

$$
n_{t}^{I *}(p=1)=\frac{(1-\alpha) E_{t}\left(R_{t+1}\right)}{2 c_{t}+v-E_{t}\left(R_{t+1}\right)} \geq n_{t}^{* *}
$$

Proposition 2. When full deposit insurance with free entry is possible, there exists a trade-off on the growth factor between the cost of full deposit insurance and its benefit, so that full deposit insurance does not necessarily increases growth.

Individual income and savings may be adversely affected by the deposit insurance tax, depending on the realization of the macro shock, which slows down growth. However, deposit insurance simultaneously increases the probability of success of banks (since the probability of success is now equal to one with full deposit insurance). This implies a significant increase in collected deposits by each banks $\left(l_{t}^{I *}\right)$ and the number of banks $\left(n_{t}^{I *}\right)$, hence boosting growth.

Independently of the trade-off highlighted in Proposition 1, one should keep in mind that the joint effect of the rise of the probability of success leading to an increase of 
$l^{I *}$ and of $n^{I *}$ is that savings are more likely to be collected on the whole circle (the proportion of depositors becomes unity). Since growth depends on the collection of deposits, this is also a reason explaining why the growth rate attains its highest level when there is full deposit insurance, although it is not necessary the case, as indicated in Proposition 1 :

$$
G_{t}=\frac{w_{t}}{K_{t}}=\left\{u_{t}\left(\frac{1-\alpha}{\alpha}\right) E_{t-1}\left(R_{t}\right)-\mathbf{1}_{\left\{R_{t}<E_{t-1}\left(R_{t}\right)\right\}}\left[\left(1-u_{t}\right) E_{t-1}\left(R_{t}\right)-c_{t+1}\right]\right\}
$$

We then evaluate the expected aggregate welfare for a newly born generation on date $t-1$. In the case of "non touching" deposit markets, it is given by its expected consumption at date $t+1$ :

$$
\begin{aligned}
E_{t-1}\left[\frac{U_{t}^{I}}{K_{t-1}}\right]= & \frac{1}{1+\rho} 2 n^{I *}\left\{\int_{0}^{l^{I *}}\left[r^{I *}-\delta \cdot i\right] d i+\int_{l^{*}}^{1 / 2 n^{I *}} v d i\right\} \\
& \cdot\left(E_{t-1}\left[u_{t}\left(\frac{1-\alpha}{\alpha}\right) E_{t-1}\left(R_{t}\right)\right]\right. \\
& \left.-\int_{\underline{-} E_{t-1}\left(R_{t}\right)}^{E_{t-1}\left(R_{t}\right)}\left[\left(1-u_{t}\right) E_{t-1}\left(R_{t}\right)-c_{t+1}\right] d F(R)\right)
\end{aligned}
$$

where the first term in curly brackets is similar to (3.6) for $p_{t}^{* *}=1$.

Proposition 3. There exist of trade-off on households welfare between the cost of finance of full deposit insurance and its benefit (the increase of the expected return on deposits) so that full deposit insurance does not necessarily increase welfare.

On the one hand, expected individual income and savings decreased due to the expected income loss necessary to insure the savings of the old generation. On the other hand, the expected return on the young generation's savings increases due to the rise of the probability of success of banks up to unity. This, in turn, implies a rise of the number of depositors for each banks $\left(l^{I *}\right)$ and a rise of the number of banks $\left(n_{t}^{I *}\right)$. However, if the cost of finance of deposit insurance exceed its benefits, it will not increase welfare.

We exhibit a numerical case where welfare maximization suggests to introduce this kind of deposit insurance (as the most usual belief is that it is inefficient). We assume endogenous growth, so that $E_{t-1}\left(R_{t}\right)=A \alpha$. It is convenient to use $R=$ $A \alpha(1-m+X)$ where $X$ follows a beta distribution $\beta(a, b)$ on $[0,1]$ with a mean $m=E[X]=a /(a+b) \in] 0,1[$. In that case, $u=1-m+X$, and $u=1-m$. We check the condition for the feasibility of full deposit insurance to be fulfilled. For simplicity, we assume that the fixed cost of a given bank is proportional to the share of aggregate output financed by that bank such that $C_{t}=f \frac{E_{t}\left[Y_{t+1}\right]}{n}$, which is also a 
rather realistic assumption. In that case, the intermediation costs ratio is a constant $c=f A{ }^{23}$ Regarding the other parameters, we provide here an example where $\rho=0$, $A=3.7, \alpha=0.32, c_{t}=0.5, v=0.2, \delta=0.975, a=0.2, b=2$. Numerical simulations show that this is an example where welfare is higher with deposit insurance $\left(E_{t-1}\left[U_{t}^{I}\right] / K_{t-1}=0.35\right)$ than without deposit insurance $\left(U_{t}^{a} / K_{t-1}=0.19\right)$. Due to the market share extension effect, the equilibrium number of banks controls a market share which entirely covers the circle. As the proportion of depositors is unity, the number of banks decreases with respect to the case of free entry without deposit insurance $\left(n^{I *}=1.01\right.$ to be compared to $\left.n^{*}=1.43\right)$.

One could also show that such a deposit insurance scheme is preferable to another scheme where taxes would be levied on the same generation but before the crisis arises (i.e. when they are young) with their savings invested in the safe storage technology with a return $v .^{24}$

\section{Reduction of excess capacities}

We now compare restrictions to entry with respect to deposit insurance with free entry, in this context of imperfect competition and bankruptcy costs for banks. By contrast with full deposit insurance, restrictions to entry can always be implemented. A first result concerns the equilibrium when the probability of success of banks is zero.

Proposition 1. Prevention of sunspot-led systemic bank run (the case for $p=0$ ):

(i) Full deposit insurance (with or without free entry) does eliminate a sunspot-led systemic bank run.

(ii) Restrictions to entry or an incomplete deposit insurance with free entry do not eliminate a sunspot-led systemic bank run..

With full deposit insurance, the probability of success is one, and no sunspot led bank run can occur. Restrictions to entry have the virtue of increasing the probability of success of banks, but not up to one. Even in the extreme case of a monopoly in the banking sector, this monopoly faces a non-zero probability of default related to the existence of a macro-economic shock. With incomplete deposit insurance, some states of nature are not insured, so that there remains a non-zero probability of default of banks. Therefore, restrictions to entry or incomplete deposit insurance do not remove a sunspot-led bank run.

\footnotetext{
${ }^{23}$ The welfare would be only altered at the margin by the ratio $c_{t+1} / c_{t}$ stating the increase of competition between date $t$ and date $t+1$, if the fixed intermediation cost is not indexed on a growing factor. If it is the case, the gradual decrease of the ratio of the intermediation cost with respect to production creates a specific dynamic which converges only in the infinite horizon to perfect competition in the intermediation sector (Gali [1995]). On the contrary, the deposit market remains concentrated in developped countries (except when a specific regulation inhibits concentration as in the U.S.), so that Gali's result is not asymptotically relevant when it is applied to the banking sector.

${ }^{24}$ The proof is available from the authors upon request.
} 
We can now compare the welfare changes with these two kinds of prudential policies, without taking into account the risk of a confidence crisis $(p=0)$. The government could determine the number of banks or the that maximises welfare. ${ }^{25}$ If this number is lower than in the case of free entry, there exists excess capacities. If not, restrictions to entry have to be prohibited. Public authorities would make an arbitrage between stability of the banking system and competitive efficiency. On the one hand, imperfect competition implies the existence of rents in banking activity. On the other hand, these rents decrease the probability of bankruptcy and the associated bankruptcy costs. When the proportion of depositors is below unity, we adapt the general expression for welfare (3.7) in order to simplify the maximization: ${ }^{26}$

$$
\begin{aligned}
\frac{U_{t}^{a}}{K_{t}} & =\frac{1}{(1+\rho)}\left[\left(\frac{p r-v}{2}\right) G_{t}+v \frac{w_{t}}{K_{t}}\right]=\frac{1}{(1+\rho)} \frac{w_{t}}{K_{t}}\left[(p \cdot r-v) \cdot n \cdot\left(\frac{p \cdot r-v}{\delta L}\right)+v\right] \\
& =\frac{1}{(1+\rho)} \frac{w_{t}}{K_{t}} \frac{1}{\delta L} W(n, r, p)
\end{aligned}
$$

With $W$ defined below. The number of banks that maximises the expected welfare (for a given stock of capital at date $t-1$ ) obtains under the constraints defining an equilibrium for a given number of banks:

$$
n \in \operatorname{Arg} \max W(n, r, p)=\operatorname{Arg} \max \left(n(p r-v)^{2}+v \delta L\right)
$$

subject to:

$$
\begin{aligned}
1 & \leq n \leq n^{* *}<\frac{L}{2\left(\frac{p^{* *} r^{* *}-v}{\delta}\right)} \\
p(r) & =1-F\left(r+c_{t+1}\right) \\
r & =\frac{1}{2}\left\{E_{t}\left[R_{t+1}\right] \cdot\left[1+\frac{\alpha-1}{n}\right]+\frac{v}{p}\right\} \Leftrightarrow n(r, p)=\frac{(1-\alpha) E_{t}\left[R_{t+1}\right]}{E_{t}\left[R_{t+1}\right]-2 \cdot r+\frac{v}{p}}
\end{aligned}
$$

The inequality constraints imply that (i) at least one bank exists, (ii) banks have at least zero profit (the case for free entry is a corner solution) and (iii) in the case of free entry, the proportion of depositors is below unity, so that the expression of welfare is the right one. According to the last equality constraint which determines the mark down on the posted deposit rate, $n$ is increasing monotonically in the rate of interest on deposits for a given probability of bankruptcy. Welfare $W(n(r, p), r, p(r))=$ $H(r, p(r))$ is an increasing function in both arguments $\left(H_{r}>0, H_{p}>0\right)$. We can express the first order condition as:

$$
H_{r}-f\left(r+c_{t+1}\right) H_{p}=0
$$

\footnotetext{
${ }^{25}$ In practical terms, government can forbid entry of foreign banks or of new banks, favour merger policy or determine the deposit rate (Mishkin (2000)).

${ }^{26}$ The case when the proportion of depositors is unity is available from the authors upon request.
} 
An increase in the deposit interest rate implies an arbitrage between the rise in households' welfare due to a higher return on saving and a reduction due to the increased instability of the banking system measured by an increased probability of default. Such a phenomenon is not always the rule in this model. This lead to the following proposition:

Proposition 2. Condition for a trade-off between instability and efficiency:

The number of banks maximising welfare corresponds to an interest rate on deposit $r(n)$ such that: $H_{r}-f\left(r(n)+c_{t+1}\right) H_{p}=0$.

(i) If this interest rate is strictly beyond the deposit rate with free entry $r(n)<$ $E_{t}\left[R_{t+1}\right]-c_{t+1}$, then restrictions to entry increase welfare.

(ii) If the interest rate maximising welfare is over the deposit rate with free entry $\left(r(n) \geq E_{t}\left[R_{t+1}\right]-c_{t+1}\right)$, then setting such an interest rate leads to negative profits for banks. In this case, the corner solution with free entry maximizes welfare, because, at this level of the deposit rate, the increase in competitive efficiency dominates the decrease in expected stability $\left(H_{r}>f\left(r+c_{t+1}\right) H_{p}\right)$.

Excess capacities appear when small shifts of deposit rates change widely the probability of default of banks, i.e. when the distribution of risk is concentrated at the average $E_{t}\left[R_{t-1}\right]=r^{* *}+c_{t}$ corresponding to the case of free entry.

For the same parameters as in the preceding section, welfare in the case of free entry is measured by $U_{t}^{a} / K_{t}=0.19$ (which corresponds to $n^{* *}=1.43$ banks). An interior solution exists which maximises welfare $\left(U_{t}^{a} / K_{t}=0.51\right)$ for a lower number of banks $(n=0.34) .{ }^{27}$ Nonetheless, the number of banks which maximises growth is different from the one which maximises welfare. Finally, in this particular case, welfare with a full deposit insurance is higher than welfare with entry regulation (although a combination of the two regulatory program is also possible).

The existence of the trade-off between efficiency and stability lead to an additional proposition on full deposit insurance and restriction to entry:

Proposition 3. Full deposit insurance with restrictions to entry decrease welfare (excluding the sunspot equilibrium) with respect to full deposit insurance with free entry.

Without full deposit insurance, the benefit of restrictions to entry relies on the increase of this probability of success, which decreases expected bankruptcy costs. With full deposit insurance, the probability of success is at its maximal level (one). It is therefore not changed by adding restrictions to entry. But the costs of restrictions to entry, related to a higher mark-down for depositors, do affect negatively welfare with deposit insurance. Minimizing the costs of imperfect competition with deposit insurance lead to support free entry.

In the general case, however, not only a full deposit insurance cannot always be implemented if the lower bound on the return is too low, but also the expected cost of

\footnotetext{
${ }^{27}$ Other simulation as well as the computer program are available upon request from the authors.
} 
deposit insurance may exceed its expected benefit, namely the reduction of bankruptcy costs associated with systemic risk in the banking system.

\section{Conclusion}

The paper shows that how a trade off between the deadweight loss associated with imperfect competition and the deadweight loss associated with bankruptcy costs of banks affects the efficiency of the financial intermediation sector, investment and growth. We did a horse race between two kinds of public intervention in the banking activity based on the possibility of this trade-off: deposit insurance with free entry versus restrictions to entry. Both policies require a careful assessment of their costs and benefit on welfare. It turns out that they are not always welfare maximising, even when bankruptcy costs do exist. The balance shifts towards deposit insurance as it is able to eliminate bankruptcies and therefore banking crisis related to a coordination problem of depositors expectations. However, not only a full deposit insurance cannot always be implemented if the lower bound on the return is too low, but also the expected cost of deposit insurance financed by intergenerational transfers borne by the young generation may exceed its expected benefit, the increase of the expected return on deposits.

Further research should deal with limited liability of intermediaries and consider the effect of other forms of prudential supervision, where for example the fixed cost in the banking activity is related to capital requirements.

\section{References}

[1] Allen, F. and D. Gale [1999] Bubbles and crises, Economic Journal (Forthcoming).

[2] Bensaïd B. and De Palma A. [1995] Politique monétaire et concurrence bancaire. Annales d'Economie et Statistiques, 40, 161-176.

[3] Berger A.N., Kashyap A.K. and Scalise J.M. [1995]. The Transformation of the U.S. Banking Industry: What a Long, Strange Trip It's been. Brookings Papers on Economic Activity. 2, 55-218. $f$

[4] Berger A.N. and Hannan T. H. [1998]. The Efficiency Cost of Market Power in the Banking Industry: A Test of the Quiet Life and Related Hypotheses. Review of Economics and Statistics, 80(3), 454-465.

[5] Bhattacharya S. Boot A.W.A., Thakor A.V. [1998]. The Economics of Bank Regulation. The Journal of Money, Credit and Banking, 30(4), 745-770. 
[6] Bordo M.D., Rockoff H., and Redish A. [1994]. The U.S. Banking System From a Northern Exposure: Stability versus Efficiency. The Journal of Economic History, 54(2), 325-341.

[7] Bordo M.D., Rockoff H., and Redish A. [1996]. A Comparison of the Stability and the Efficiency of the Canadian and American banking systems, 1870-1925. Financial History Review. 3(1), 49-68.

[8] Besanko D. and Thakor A.V. [1992] Banking Deregulation: Allocational Consequences of Relaxing Entry Barriers. Journal of Banking and Finance.16, 909-932.

[9] Besanko D. and Thakor A.V. [1992]. Relationship Banking, deposit insurance and banks portfolio choice. in "Capital Markets and Financial Intermediation" (C. Mayer and Vives X., eds) pp.292-319. Cambridge Univ. Press, Cambridge, $\mathrm{UK}$.

[10] Carr, J., Mathewson and N. Quigley [1995] Stability in the absence of deposit insurance: the Canadian Banking system, 1890-1966, Journal of Money, Credit and Banking, november, vol 27, 4, Part 1, pp. 1138-1157.

[11] Carroll C. and Weil D. [1994] Saving and growth: a reinterpretation. CarnegieRochester Series on Public Policy 40, 133-192.

[12] Chan, Y., Greenbaum, S. and Thakor, A. [1992] Is Fairly priced deposit insurance possible. Journal of Finance, 47.

[13] Davis, E.P. and S. Salo (1998) Excess capacity in EU and US banking sectors: conceptual, measurement and policy issues, Special Paper \# 105, Financial markets Group, London School of Economics.

[14] Diamond D. [1984]. Financial Intermediation and Delegated Monitoring. Review of Economic Studies. 939-414.

[15] Diamond D. and Dybvig [1983]. Bank runs, deposit Insurance and Liquidity. Journal of Political Economy. 20. 331-368.

[16] Diamond P.A. [1965]. National Debt in a Neoclassical Growth Model. American Economic Review. 55(5). 1126-1150.

[17] Friedman M. and Schwartz A. [1963]. A Monetary History of the United States, 1867-1960. Princeton University Press. Princeton, New Jersey.

[18] Fry M.J. [1995] Money, Interest and Banking in Economic Development. The John Hopkins University Press. 
[19] Frydl E. J. [1993] Excess capacity in the financial sector, causes and issues, in Studies on excess capacity in the financial sector, Federal Reserve Bank of New York.

[20] Gali J. [1995]. Product diversity, Endogenous Markups, and Development Traps. Journal of Monetary Economics 36(1), 39-63.

[21] Gendreau B.C. and Prince S.S. [1986]. The private cost of bank failures: some historical evidence. Federal Reserve Bank of Philadelphia Business Review.

[22] Gennotte G. and Pyle D. [1991]. Capital Controls and Bank Risk. The Journal of Banking and Finance, 15, 805-824.

[23] John K., John T.A. and Senbet L.W. [1991]. Risk Shifting Incentives of Depository Institutions: A New Perspective on Federal Deposit Insurance Reform. Journal of Banking and Finance. 15(4-5), 895-915.

[24] Keeley M.C. [1990]. Deposit Insurance, Risk and Market Power in Banking. The American Economic Review, 80, 1183-1200.

[25] Marcus A.J. [1984]. Deregulation and Bank Financial Policy. The Journal of Banking and Finance, 8, 557-565.

[26] Maddison A. [1995]. Monitoring the World Economy 1820-1992. O.E.C.D. Development Center Studies.

[27] Matutes C. and Vives X. [1996]. Competition for deposits, fragility and insurance. Journal of Financial Intermediation, 5, 184-216.

[28] Matutes C. and Vives X. [2000]. Imperfect Competition, Risk Taking and Regulation in Banking. European Economic Review. 44(1), 1-34.

[29] Mishkin F.S. [2000]. Prudential Supervision: Why is it Important and what are the Issues. NBER working paper 7926.

[30] Qi J. [1994]. "Bank Liquidity and Stability in an Overlapping Generation Model". Review of Financial Studies, 75, 389-417.

[31] Mulligan C.B. and Sala-I-Martin [1996]. Adoption of Financial Technologies: Implications for Money Demand and Monetary Policy, NBER working paper 5504.

[32] Rajan R. [1996] Why Banks have a future: an economic rationale. Banca d'Italia Themi di Discussione October 1996.

[33] Romer P. [1986] Increasing Returns and Long Run Growth. Journal of Political Economy. 94(5). 1002-1037. 
[34] Salop S. [1979] Monopolistic Competition with Outside Goods. Bell Journal of Economics. 10(1). pp. 141-156.

[35] Suarez J. [1998]. Risk-taking and the Prudential Regulation of Banks. Investigationes Economicas. 22(3), 307-36.

[36] Williamson S.D. [1987] Transactions Costs, Inflation, and the Variety of Intermediation Services. Journal of Money, Credit and Banking. Vol 19, No 4, pp. 484-498. 